Review

\title{
Ulasan: Sarang Burung Walet sebagai Pangan Fungsional
}

\author{
(Reviews: Edible Bird's Nest as Functional Food) \\ Dede Sri Wahyuni' ${ }^{*}$, Hadri Latif ${ }^{2}$, Mirnawati B Sudarwanto ${ }^{2}$, Chaerul Basri ${ }^{2}$ \\ 'Balai Besar Karantina Pertanian Soekarno Hatta, Badan Karantina Pertanian, Gedung Karantina Pertanian Bandara \\ Internasional Soekarno Hatta, Pajang, Benda, RT.001/RW.010, Pajang, Benda, Kota Tangerang, Banten 15126 \\ ${ }^{2}$ Departemen Ilmu Penyakit Hewan dan Kesehatan Masyarakat Veteriner, Fakultas Kedokteran Hewan, \\ Institut Pertanian Bogor, Jl. Agatis Kampus IPB Dramaga Bogor, 16680 \\ *Penulis untuk korespondensi: desriwahyuni@apps.ipb.ac.id \\ Diterima 7 April 2021, Disetujui 3 Agustus 2021
}

\begin{abstract}
ABSTRAK
Sarang burung walet (SBW) merupakan sarang yang berasal dari saliva beberapa spesies burung keluarga Apodidae, terutama spesies Aerodramus fuciphagus dan A. maximus. Indonesia merupakan negara penghasil SBW terbesar dengan menyumbang $85 \%$ dari pasar dunia. Sarang burung walet sejak lama telah digunakan dalam pengobatan tradisional Tiongkok. Komponen utama dari SBW adalah glikoprotein, yang diyakini terlibat dalam jalur biologis yang beragam untuk meningkatkan kesehatan. Berbagai penelitian telah dilakukan untuk mengkarakterisasi peptida dan glikoprotein SBW sebagai bahan bioaktif makanan fungsional. Ulasan ini bertujuan untuk memberikan informasi mengenai potensi SBW sebagai produk makanan fungsional berdasarkan kandungan bahan bioaktif dan sifat fisikokimia yang dimilikinya. Sarang burung walet digunakan sebagai bahan makanan, baik dengan menyajikan dalam bentuk utama atau menggabungkan dengan bahan lain yang meningkatkan nilai tambah produk pangan seperti minuman siap saji, yoghurt, roti daging, es krim, mie dan cokelat. Potensi komponen bioaktif SBW sebagai pangan fungsional meliputi klaim penurunan risiko penyakit dan klaim fungsi lain. Klaim penurunan risiko penyakit antara lain anti inflamasi, aktifitas antivirus, meningkatkan kesehatan jantung dan pembuluh darah, meningkatkan imunitas, efek neuroprotektif, dan mencegah penyakit diabetes. Klaim fungsi lain meliputi ploriferasi sel, aktifitas epidermal growth factor (EGF) dan anti penuaan, memperbaiki fungsi saluran pencernaan, peningkatan kekuatan tulang, meningkatkan fungsi saluran reproduksi, dan antioksidan.
\end{abstract}

Kata kunci : sarang burung walet, burung walet, pangan fungsional, glikoprotein

\begin{abstract}
Edible Bird Nest (EBN) is a nest produced from the saliva of the bird species from the Apodidae family, especially the species Aerodramus fuciphagus and A. maximus. Indonesia is the biggest EBN-producing country by contributing $85 \%$ of the world market. Edible Bird Nest is used medically in traditional Chinese medicine. The main component of EBN is a glycoprotein, which is believed to be involved in diverse biological pathways to improve health. Various research have been carried out to characterize EBN peptides and glycoprotein as functional bioactive materials, mostly functional foods. This review aims to provide an overview of the potential of SBW as a functional food product based on its bioactive ingredients and physicochemical properties. Edible Bird's Nest is used as a food ingredient, among others, by combining EBN with other foods to increase added value with food products such as drinks, yoghurt, meat bread, ice cream, noodles, and chocolate. EBN bioactive components potential as functional food includes claims for reducing disease risk and claims for other functions. Claims to reduce disease risk include anti-inflammatory, antiviral activity, improved heart health and vessels, increased immunity, neuroprotective effects, and preventing diabetes. Other functional claims include cell proliferation, epidermal growth factor (EGF) and anti-aging activity, promoting digestive tract function, increased bone strength, improved reproductive tract function, and antioxidants.
\end{abstract}

Key words: Edible Bird Nest (EBN), swiftlet, functional food, glycoprotein 


\section{PENDAHULUAN}

Sarang burung walet (SBW) merupakan sarang yang dihasilkan dari saliva beberapa spesies burung walet keluarga Apodidae (Ma dan Liu, 2012a). Negara penghasil utama SBW yaitu Indonesia, Malaysia, Thailand, Vietnam, Filipina, dan China. Indonesia merupakan negara penghasil SBW terbesar dengan menyumbang $85 \%$ dari pasar dunia dan diikuti oleh Malaysia dengan menyumbang $13 \%$ dari pasar dunia (Kong et al., 2016). Sarang burung walet telah dianggap sebagai simbol kekayaan, kekuasaan, dan prestise. Kualitas SBW dan harganya bervariasi secara signifikan tergantung pada asal geografisnya (Ma dan Liu, 2012a). Secara umum, SBW dari Indonesia memiliki harga yang lebih tinggi dibandingkan dari negara lain (Lee et al., 2017).

Sarang burung walet digunakan dibidang medis dalam pengobatan tradisional Tiongkok pada masa Dinasti Tang (618-907 M) dan dinasti Sung (9601279 M) (Koon dan Cranbrook, 2002). Sarang burung walet kaya akan nutrisi, protein yang larut dalam air, karbohidrat, zat besi, garam, serat organik, dan lainlain (Quek et al., 2018). Sarang burung walet terbukti secara ilmiah memiliki manfaat dalam pencegahan penyakit dengan cara memperkuat sistem kekebalan tubuh (Haghani et al. 2016), merangsang pertumbuhan epidermis (Kong et al. 1987), menekan produksi tumor necrosis factor-alpha (TNF-a) (Aswir dan Wan Nazaimoon, 2011), menghambat infeksi virus (Guo et al., 2006), meningkatkan respirasi dan menurunkan masalah pencernaan (Wong, 2013).

Berbagai macam produk olahan SBW telah diperdagangkan dengan mengikuti kemajuan teknologi di bidang pangan. Ekstrak SBW digunakan sebagai salah satu bahan utama dalam produk nutraseutikal, seperti suplemen kesehatan. Industri kosmetik menggunakan ekstrak SBW dalam produk kecantikan yang digunakan untuk regenerasi sel kulit (Kong, 1987). Produk tersebut diklaim dapat mempertahankan keremajaan kulit dan menyebabkan kulit lebih cerah sehingga menunjukkan efek anti-penuaan (Koon dan Cranbrook, 2002). Komponen utama dari SBW adalah glikoprotein, yang diyakini terlibat dalam jalur biologis dalam meningkatkan kesehatan manusia.

Komponen SBW yang telah dikarakterisasi sebagai bahan bioaktif pangan fungsional berupa petida (Wong et al., 2017) dan glikoprotein (Shim et al., 2016) yang aman untuk dikonsumsi manusia. Eksplorasi manfaat mengkonsumsi SBW diteliti baik dalam bentuk sup, suplemen, maupun produk makanan lainnya (Babji, 2014). Ulasan ini bertujuan untuk memberikan informasi mengenai potensi SBW sebagai produk makanan fungsional berdasarkan kandungan bahan bioaktif dan sifat fisikokimia yang dimilikinya.

\section{METODE}

Artikel ini disusun dengan melakukan review terhadap berbagai literatur yang berkaitan dengan SBW sebagai pangan fungsional. Penulisan artikel dilakukan dengan menggunakan pencarian karya ilmiah lengkap, google scholar (google cendekia), Elsevier, medline with full text, Proquest dan Pubmed, dan EBSCO. Pencarian menggunakan kata kunci pangan fungsional, sarang burung walet, bahan bioaktif SBW, sifat fisikokimia SBW, dan pengaruh bahan bioaktif SBW terhadap kesehatan manusia. Pencarian artikel dilaksanakan mulai Bulan Agustus 2020 sampai dengan Februari 2021.

Artikel yang sesuai dengan kriteria inklusi dan eksklusi untuk selanjutnya dianalisis. Studi literatur ini menggunakan pustaka terbitan tahun 1987-2019 yang dapat diakses fulltext dalam format pdf, html, dan scholarly (peer reviewed journals). Artikel disintesis menggunakan metode naratif dengan cara mengelompokkan data-data hasil ekstraksi yang sejenis untuk menjawab tujuan dari tulisan ini. Jurnal yang sesuai dengan kata kunci tersebut ditemukan 127 buah. Setelah asesment kelayakan, diperoleh 86 jurnal full text yang dapat di-review.

\section{HASIL DAN PEMBAHASAN}

\section{Sarang Burung Walet}

Sarang burung walet di Asia Tenggara terutama dihasilkan oleh burung walet dari spesies Aerodramus fuciphagus (Viruhpintu et al., 2002; Lin et al., 2009; Chua dan Zukefli, 2016; Fujita dan Leh, 2020) dan Aerodramus maximus (Viruhpintu et al., 2002; Chua dan Zukefli, 2016; Fujita dan Leh, 2020). Burung walet $A$. fuciphagus di Kalimantan memiliki empat subspesies yaitu Aerodramus fuciphagus vestitus, A. fuciphagus germani, A. fuciphagus perplexus dan $A$. fuciphagus fuciphagus (Fujita dan Leh, 2020). Burung walet umumnya membentuk koloni besar di gua-gua gelap atau lingkungan seperti gua dengan menggunakan kemampuannya untuk bernavigasi dalam kegelapan melalui ekolokasi (Chantler dan Driessens, 2002).

Burung walet membangun sarangnya menggunakan saliva yang tersusun oleh komponen seperti pati. Komponen ini berfungsi untuk melindungi telur 
dan sarang (Goh et al., 2001). Sekresi saliva mengeras akibat adanya paparan udara. Sarang burung walet terutama dibangun oleh burung walet jantan dan dibuat hampir seluruhnya dari saliva yang disekresikan oleh dua kelenjar salivary sublingual. Ketika membangun sarangnya, burung walet menggunakan saliva untuk mengikat bahan sarang secara bersama-sama dan menempelkannya ke dinding vertikal gua di daratan atau di tepi laut (Kang et al., 1991) atau di rumah walet buatan (Babji et al., 2015). Berat sarang bisa 1-2 kali berat badan burung walet. Sarang ini hanya bisa menopang induk dan anaknya. Proses konstruksi sarang dapat memakan waktu sekitar 35 hari (Marcone, 2005).

Kualitas SBW di pasaran dibedakan berdasarkan warnanya yaitu putih, kuning (emas), dan merah (Chua dan Zukefli, 2016). Sarang burung walet berwarna putih yang bersih dari kotoran atau bulu, bentuk mangkuk sempurna, tidak cacat atau pecah dan berukuran lebar minimal tiga jari dikelompokkan sebagai SBW bermutu tinggi (Mardiastuti, 1997). Sarang burung walet yang dihasilkan A. maximus lebih berat daripada SBW yang dihasilkan A. fuciphagus. Massa kering SBW yang dihasilkan A. maximus terdiri dari sekitar 10\% bulu, sehingga warnanya menjadi lebih hitam dibandingkan SBW yang dihasilkan A. fuciphagus. Protein dalam SBW yang dihasilkan A. maximus memiliki $7 \%$ lebih sedikit dibandingkan SBW yang dihasilkan A. fuciphagus serta lipid 4\% lebih sedikit dibandingkan SBW yang dihasilkan A. fuciphagus (Kang et al., 1991). Kualitas SBW dipengaruhi oleh musim, cara pemanenan, gangguan hama, dan lingkungan (Soehartono dan Mardiastuti 2003).

\section{Proses Produksi Sarang Burung Walet}

Menurut Jong et al. (2013) secara umum produksi SBW terdiri atas beberapa sub proses antara lain budidaya di rumah walet, pemanenan, pembersihan sarang burung walet, proses pengeringan, pembentukan kembali SBW, penyimpanan, dan pengemasan. Rumah walet biasanya merupakan suatu bangunan yang dibangun oleh manusia dengan lingkungan yang didesain khusus, dilengkapi dengan rekaman suara burung walet, kontrol suhu dan kelembaban untuk menarik burung walet (Fujita dan Leh 2020). Rumah walet merupakan tempat yang mengakomodasi burung walet untuk membuat sarangnya. Burung walet diundang dengan menggunakan suara burung walet tiruan untuk menarik burung tinggal di rumah walet dan menghasilkan sarang burung. Rumah walet harus menjaga agar burung walet terlindung dari ancaman predator seperti burung hantu, kelelawar, serta melindungi dari ancaman hama seperti tikus, semut, dan kecoa yang dapat menghancurkan SBW (Fujita dan Leh 2020). Salah satu bentuk bangunan rumah walet dapat dilihat pada Gambar 1.

Pemanenan adalah proses mengumpulkan sarang burung walet dari rumah walet. Proses memanen SBW harus memerhatikan waktu dan cara memanen yang tepat agar walet tidak stres. Pemanenan sarang burung walet terbagi atas panen tetasan, panen rampasan, panen buang telur, dan panen pilihan (Nugroho dan Budiman, 2011). Pemanenan dapat dilakukan dengan menggunakan pisau yang tajam (Jong et al., 2013), menggunakan tangan (Ma dan Liu, 2012), menggunakan tongkat bambu atau besi jika sarang yang dibangun tinggi (Marcone, 2005). Metode panen di Indonesia dapat dilihat pada Gambar 2 dan menghasilkan SBW dalam bentuk kotor seperti pada Gambar 3.

Sarang burung walet yang telah dikumpulkan, selanjutnya dibersihkan. Sarang burung walet mentah direndam terlebih dahulu dalam air untuk melembutkan SBW supaya mudah dibersihkan. Bulu-bulu yang berada dalam SBW mentah dibuang dan dibersihkan. Bulu yang lebih besar biasanya dicabut dengan pinset, sementara bulu yang halus bisa dihilangkan dengan teknik pengapungan atau dicabut pinset dengan menggunakan kaca pembesar. Serat sarang burung yang panjang dipisahkan dengan hati-hati untuk menghasilkan SBW kelas premium (Fujita dan Leh 2020). SBW yang telah dicuci bersih tidak mengalami perubahan warna dibandingkan dengan sebelum dicuci. Perusahaan pemrosesan biasanya tidak membersihkan SBW putih berkualitas premium karena sulit untuk mengembalikannya ke bentuk aslinya setelah direndam dalam air. Setelah dikeringkan dengan cara diangin-anginkan pada suhu ruang, sarang-sarang tersebut dikemas untuk dijual. Proses ini membutuhkan waktu 8 jam untuk membersihkan sekitar 10 sarang (Koon dan Cranbrook, 2002; Jong et al., 2013). Sarang burung walet kering biasanya rapuh sehingga dalam proses pengiriman dilindungi dari kerusakan dengan menggunakan spons atau bubble wrap (Jong et al., 2013).

Beberapa tahun terakhir, SBW dalam produk makanan lain digunakan untuk meningkatkan variasi, kualitas, dan rasa. Sarang burung walet digunakan untuk meningkatkan nilai tambah produk pangan seperti minuman, yoghurt, roti daging, es krim, mie, dan cokelat (Babji et al., 2014). Komponen bioaktif 

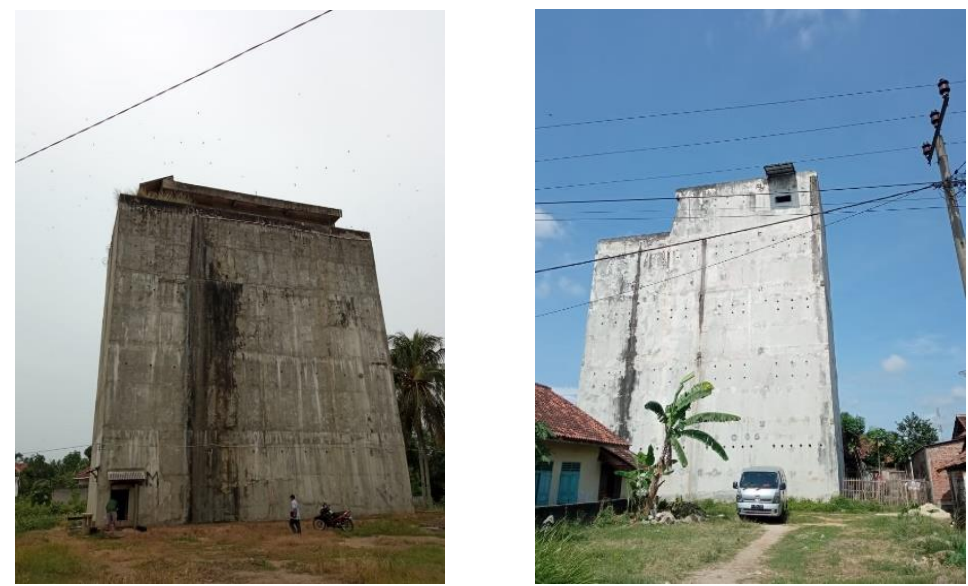

Gambar 1 Bangunan rumah walet

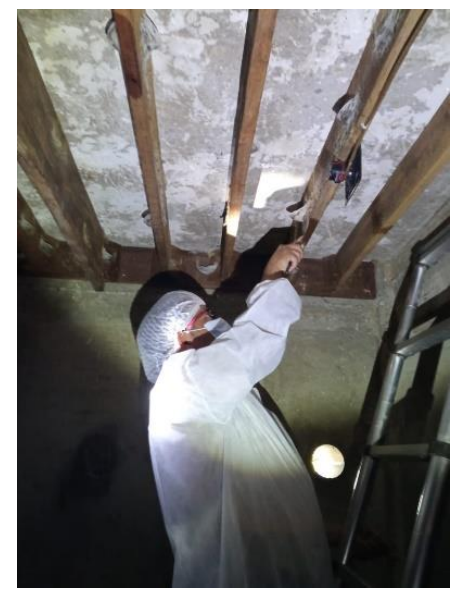

Gambar 2 Proses pemanenan sarang burung walet

SBW dapat bermanfaat untuk meningkatkan kualitas produk serta berkontribusi terhadap kesehatan.

\section{Komponen Bioaktif SBW Sebagai Pangan Fungsional}

Analisis proksimat dalam SBW sangat bervariasi yang menunjukkan kemungkinan perbedaan komposisi dalam saliva yang dikeluarkan selama periode 35 hari ketika sarang sedang dibangun (Marcone, 2005). Berdasarkan analisis komposisi, glikoprotein SBW yang dimurnikan mengandung sekitar $63 \%$ protein, $21 \%$ total sakarida dan $14 \%$ asam sialat (Marcone, 2005; Saengkrajang et al., 2013; Zhang et al., 2012; Xu et al., 2019). Susunan komposisi (dari tertinggi ke terendah) adalah protein, karbohidrat, abu, dan lemak. Komposisi analisis proksimat SBW ditunjukkan pada Tabel 1.
Protein tinggi dalam SBW merupakan indikator dari kualitas dan kelimpahan pakan di lingkungan rumah walet (Marcone, 2005). Analisis asam amino pada SBW merah dan SBW putih menunjukkan kandungan asam amino yang sangat mirip. Sarang burung walet mengandung semua jenis asam amino esensial. Asam amino yang paling dominan adalah serin, treonin, asam aspartat, asam glutamat, prolin, dan valin (Kathan dan Weeks, 1969). Sarang burung walet putih kaya akan dua asam amino aromatik, yaitu, fenilalanin dan tirosin (Marcone, 2005). Sarang burung walet mengandung lebih banyak asam amino asam dibandingkan dengan asam amino basa (Ma dan Liu, 2012a).

Berdasarkan kandungan asam amino, SBW dapat menyediakan asam amino esensial yang dibutuhkan oleh tubuh manusia untuk pertumbuhan, pemeliharaan, dan perbaikan jaringan. Beberapa kandungan asam amino esensial (misalnya lisin) pada 


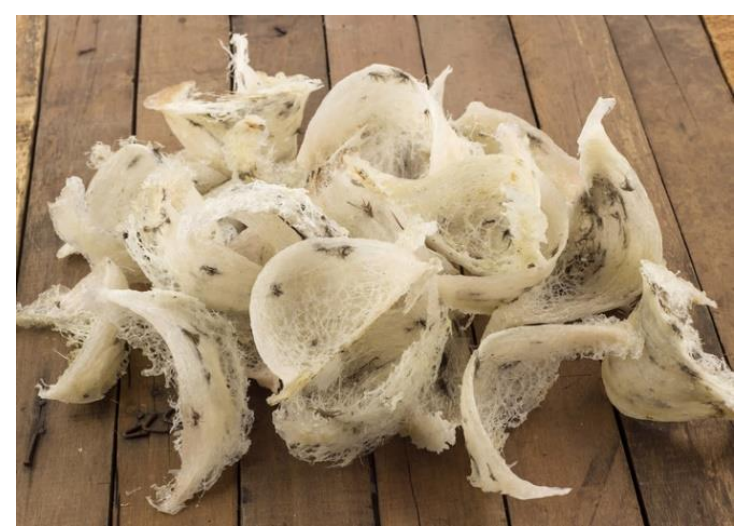

Gambar 3 Sarang burung walet kotor

Tabel 1 Bahan bioaktif SBW yang dipanen dari rumah walet di beberapa negara

\begin{tabular}{cccccccc}
\hline No. & Proksimat & $\begin{array}{c}\text { Protein } \\
(\%)\end{array}$ & $\begin{array}{c}\text { Karbohidrat } \\
(\%)\end{array}$ & $\begin{array}{c}\text { Kadar Air } \\
(\%)\end{array}$ & $\begin{array}{c}\text { Abu } \\
(\%)\end{array}$ & $\begin{array}{c}\text { Lemak } \\
(\%)\end{array}$ & Sumber \\
\hline $\mathbf{1}$ & Indonesia & 65,8 & 10 & 10.87 & 1,5 & 0,04 & (Zainab et al. 2013) \\
$\mathbf{2}$ & Thailand & 62,58 & 29,66 & 19,82 & 6,72 & 0,96 & (Saengkrajang et al. 2013) \\
$\mathbf{3}$ & Malaysia & 62 & 27,26 & 7,5 & 2,1 & 0,14 & (Marcone 2005) \\
$\mathbf{4}$ & Filipina & - & 16 & 5,58 & 1,5 & 0,05 & (Zainab et al. 2013) \\
\hline
\end{tabular}

SBW lebih tinggi dibandingkan dengan produk hewan lain (Marcone, 2005). Metionin hanya ditemukan dalam SBW putih namun tidak ada pada SBW merah (Daud et al., 2019b).

Karbohidrat merupakan komponen bioaktif tertinggi kedua dalam SBW (Zainab et al., 2013). Karbohidrat dalam SBW terdiri dari galaktosa, manosa, glukosamin, galaktosamin, dan asam sialat (Ma dan Liu, 2012a). Hasil analisis karbohidrat menunjukkan bahwa SBW putih memiliki lebih sedikit kandungan karbohidrat total dibandingkan dari SBW merah (Marcone, 2005). Glikoprotein SBW mengandung musin, misalnya, kondroitin glikosaminoglikan (GAG). Mucin glikoprotein dari SBW mengandung $\mathrm{O}$ - dan $\mathrm{N}$-glikosilprotein serta mewakili senyawa alami kaya-glikan (Yagi et al., 2008).

Glikan SBW terdiri dari enam jenis monosakarida yaitu galaktosa, manosa, fucosa, $\mathrm{N}$ asetilglukosamin, $\mathrm{N}$-asetilgalaktosamin, dan asam $\mathrm{N}$ asetilneuramin (asam sialat) (Yagi et al., 2008). Nilai derajat polimerasi (DP) dari glikan SBW berdasarkan pada struktur yang diperoleh Yagi et al. (2008) memiliki nilai dari 7 hingga 21 (rata-rata 14). Struktur glikan bercabang dengan dua cabang dalam bentuk O-glikan atau tiga cabang dalam bentuk $\mathrm{N}$-glikan. Kedua struktur mengandung galaktosa tinggi dan $\mathrm{N}$ - asetilheksosamin. O-glikan sebagai struktur utama yang terkandung dalam SBW dibandingkan dengan $\mathrm{N}$-glikan.

Jenis glikan kompleks pada SBW biasanya tidak dapat dicerna oleh sistem pencernaan lambung manusia. Bakteri usus manusia memang memiliki kemampuan untuk menemukan keberadaan glikan sebagai sumber makanannya (Koropatkin et al., 2012; Tailford et al., 2015). Glikan kompleks SBW yang mengandung heksosa, heksosamin, dan asam sialat memiliki kedekatan dengan glikus endogen dan human milk oligosaccharide (HMO). Glikan dan HMO dikategorikan sebagai senyawa prebiotik. Ketersediaan karbohidrat dalam saluran pencernaan berperan penting dalam membentuk struktur-fungsi mikrobiota. Secara khusus, beberapa bakteri usus memiliki kemampuan untuk mencari makan pada glikan yang disediakan oleh lapisan mukosa saluran pencernaan. Komunitas bakteri usus bergantung pada beberapa kelompok bakteri tertentu yang menghasilkan glikosidase. Glikosidase berfungsi pada degradasi jenis glikan SBW (Tailford et al., 2015).

Jumlah abu anorganik pada SBW merah maupun putih hampir identik (Marcone, 2005). Lebih lanjut Marcone (2005) menyatakan meskipun jumlah total mineral dari SBW merah dan SBW putih identik, SBW putih mengandung kalsium jauh lebih tinggi 
dibandingkan dengan SBW merah. Kandungan zat besi relatif lebih tinggi pada SBW merah dibandingkan dengan SBW putih (Ma dan Liu, 2012; Marcone, 2005).

Pemeriksaan lebih lanjut dari komponen lemak dalam SBW sangat kecil berupa palmitat, stearat, linoleat, dan linolenat (Marcone, 2005). Kandungan mono dan digliserida dalam SBW sangat tinggi, namun fungsi dan asalnya masih belum jelas. Kandungan ini diduga berasal dari pembelahan hidrolitik triasilgliserol yang disebabkan oleh kelembaban di dalam gua atau hasil dari tindakan enzim yang ada pada SBW (Marcone, 2005).

\section{Sifat Fisikokimia Bahan Bioaktif Sarang Burung Walet}

Protein SBW dapat diekstraksi dengan beberapa metode yaitu: panas, garam, basa, asam dan hidrolisis enzimatik. Ekstraksi panas dilakukan dengan merebus pada suhu tinggi $\left(80^{\circ} \mathrm{C}\right)$ (Kong et al., 2016). Struktur protein SBW tetap utuh dengan waktu perebusan kurang dari 1 jam. Protein dengan struktur konformasi $\beta$ tinggi lebih stabil dan tahan terhadap pencernaan gastrointestinal (Carbonaro et al., 2012).

Protein kasar dalam SBW dapat dicerna dengan baik $(96,63 \%)$ setelah melalui sistem pencernaan manusia secara in vitro. Hasil yang diperoleh dari protein SBW setelah dicerna hampir mirip dengan protein serum sapi yang mencapai tingkat kecernaan 95\% (Deutz et al., 1995). Berat molekul protein SBW bervariasi, sekitar 140,8, 64,8 dan 21,2 kDa (Utomo et al. 2014). Sebagian besar protein berukuran besar dicerna menjadi $70 \mathrm{kDa}, 40 \mathrm{kDa}$ dan di bawahnya, sementara beberapa protein besar lainnya tetap stabil (Xian et al., 2010).

Sebanyak 63\% karbohidrat yang diekstraksi dari glikan SBW dan sebanyak 78\% dari glikoprotein SBW tetap tidak tercerna dan memiliki potensi untuk dibawa ke lingkungan usus untuk difermentasi oleh mikrobiota usus sebagai bahan prebiotik. Struktur glikan SBW bentuknya menyerupai serat mamalia (You et al., 2015). Gula SBW mengandung struktur konformasi $\beta$ tinggi dalam bentuk struktur cabang O-linked dan $\mathrm{N}$-linked (Yagi et al., 2008). Komponen yang mengandung struktur $\beta$, resisten terhadap sistem pencernaan manusia (Dhingra et al., 2012; Sawicki et al., 2017).

Produksi bahan bioaktif glikoprotein SBW dengan suhu tinggi dapat menyebabkan reaksi Maillard. Reaksi Maillard adalah reaksi pencoklatan non enzimatis yang terjadi karena adanya reaksi antara gula pereduksi dengan gugus amin bebas dari asam amino atau protein. Selama reaksi Maillard, kondensasi gugus pereduksi glikan dan amino dari protein dalam SBW pada suhu tinggi membentuk produk karbonil polimerik dengan kelarutan rendah. Ikatan rangkap terkonjugasi dari produk dapat memberikan warna kecoklatan atau kekuningan (Hun et al., 2015). Karena reaksi Maillard maka warna glikoprotein yang dihasilkan akan berubah dan dapat menyebabkan bau seperti telur. Meskipun sifat sensoriknya dapat berubah namun sifat bioaktivitas spesifik seperti sifat antioksidan tidak secara signifikan berubah oleh reaksi yang terjadi (Lee, 2014).

Glikoprotein SBW dihidrolisis oleh enzim protease menjadi glikoprotein bioaktif. Metode perebusan dengan hidrolisis enzimatik terbukti menjadi teknik yang lebih efisien untuk memproduksi glikoprotein bioaktif dari SBW (Nurfatin et al. 2016). Perebusan dapat mengurai dan mengekspos glikoprotein agar terjadi hidrolisis oleh enzim. Komponen bioaktif dilepaskan oleh enzim, sehingga dapat melakukan berbagai fungsi fisiologis (Kim et al., 1999). Enzim seperti pankreatin F (Guo et al., 2006), pankreatin (Etty-Syarmila et al., 2014), pepsin (Elicia et al., 2014), flavourzyme (Elicia et al., 2014), papain (Nurfatin et al., 2016), dan alkalase (EttySyarmila et al., 2014; Nurfatin et al., 2016; Amiza et al., 2014) telah digunakan dalam hidrolisis glikoprotein bioaktif SBW.

Proses perebusan dalam melarutkan seluruh SBW diperlukan waktu 8 jam untuk SBW putih, 16 jam untuk SBW kuning, dan 40 jam untuk SBW merah. Perbedaan tersebut diduga disebabkan oleh perubahan struktur dan konformasi protein dengan warna yang berbeda (wong et al., 2017). Sarang burung walet merah mempunyai karakter kelarutan air yang lebih rendah dan sangat tahan terhadap kerja enzim dibandingkan dengan SBW putih (Abdulah et al., 2017). Glikoprotein SBW digunakan dalam pengembangan minuman karena sifat kelarutannya (Babji et al. 2014).

Kemampuan SBW untuk membentuk struktur seperti gel dapat bermanfaat pada beberapa produk makanan seperti bahan pembentuk gel, pengemulsi, reologi dan surfaktan (Pintado et al., 2015). Kandungan SBW tahan panas dengan kemampuan untuk mempertahankan struktur asli pada suhu mendidih dapat memberi manfaat pada saat proses produksi makanan (Sovrani et al., 2017). Sifat gel dari ekstrak SBW dapat bertindak sebagai surfaktan untuk komponen es krim yang menurunkan tegangan permukaan antara cairan dengan cairan atau cairan dengan padatan yang membuat ikatan molekul menjadi lebih kuat. Hal ini membuat komponen es krim memiliki titik leleh yang lebih rendah (Daud et al., 2019b). 
Sarang burung walet dijadikan bahan campuan pada chicken patties, sehingga meningkatkan laju oksidasi tanpa mempengaruhi rasa dari chicken patties. Susut masak (cooking loss), daya ikat air dan kekenyalan tekstur chicken patties dapat ditingkatkan selama penyimpanan dengan penambahan SBW (Ravisangkar et al., 2014). Kekenyalan tekstur chicken patties dipengaruhi kandungan protein dari ekstrak SBW (Han dan Bertram, 2017). Kekenyalan adalah faktor utama yang menentukan tekstur produk daging yang disukai.

Pangan Fungsional di Indonesia dikelompokan dalam klaim kesehatan (BPOM, 2011). Klaim kesehatan sebagai pangan fungsional dalam peraturan BPOM (2011) meliputi klaim penurunan risiko penyakit dan klaim fungsi lain. Oleh karena itu, potensi SBW sebagai pangan fungsional dapat dikategorikan ke dalam klaim penurunan risiko penyakit dan klaim fungsi lain sebagai berikut:

\section{Klaim Dampak SBW terhadap Penurunan Risiko Penyakit}

\section{Anti Inflamasi}

Salah satu klaim manfaat kesehatan dari SBW adalah efek antiinflamasi. Sarang burung walet secara signifikan meningkatkan kadar nuclear factorkappa B (NF-kB), interleukin (IL)-2, TNF- $\alpha$, IL-6, IL-10, IL-12 dan IL-27 (Haghani et al. 2016). Sarang burung walet juga menghambat produksi TNF- $\alpha$ dan nitrit oksida (NO) masing-masing sebesar 58\% dan 63\%, tanpa efek sitotoksik yang signifikan terhadap cellline (Vimala et al., 2012). Ekstrak SBW dalam bentuk formula, terbukti efektif dalam meningkatkan sintesis DNA pada limfosit T serta tingkat serum imunoglobulin $M$ pada tikus. Formulasi ini juga telah berhasil meningkatkan superoksida dismutase dalam eritrosit tikus dan mengurangi malondialdehid (produk lipid peroksida) pada jaringan otak tikus (Mei et al., 1994). Selain itu, ekstrak SBW dapat mengurangi pelepasan TNF-a dalam cell line makrofag monosit leukemik tikus, tetapi efek pengurangan TNF- $\alpha$ bervariasi pada SBW yang diproses atau tidak diproses. Tumor necrosis factor alpha (TNF-a) merupakan sitokin utama pada respon inflamasi akut terhadap bakteri Gram negatif dan mikroba lainnya. Infeksi yang berat dapat memicu produksi TNF dalam jumlah besar yang menimbulkan reaksi sistemik. Peningkatan kadar TNF- $a$ juga dikaitkan dengan penyakit diabetes, penyakit radang usus dan artritis reumatoid (Aswir dan Wan Nazaimoon, 2011).

\section{Aktifitas Antivirus}

Ekstrak SBW yang dihidrolisa dengan enzim pankreas (Pancreatin F) secara signifikan menghambat infeksi virus influenza (Guo et al., 2006; Haghani et al., 2016) dengan mengikat virus secara langsung baik pada manusia, unggas maupun babi (Guo et al., 2006). Penelitian lain oleh Haghani et al. (2016) melaporkan bahwa SBW memiliki sifat penghambatan neuraminidase tinggi dengan efektivitas yang sama seperti Oseltamivir Fosfat (Tamiflu). Aktivitas pengikatan virus oleh ekstrak SBW yang berasal dari gua jauh lebih kuat daripada SBW yang berasal dari rumah walet (Guo et al., 2006). Ekstrak SBW memiliki kemampuan menghambat hemaglutinasi oleh virus influenza pada sel darah merah dan menetralkan virus influenza yang menginfeksi sel ginjal (madindarby canine kidney epithelial cells) (Guo et al., 2006). Beberapa jenis patogen seperti virus parainfluenza, virus influenza $A$, virus influenza $B$, virus influenza $C$, koronavirus, rotavirus, virus newcastle diseases, highly pathogenic avian influenza (HPAI) $\mathrm{H}_{5} \mathrm{~N} 1$ dan bakteri (kolera) dapat mengenali asam sialat yang terikat dengan galaktosa atau $\mathrm{N}$ acetylgalactosamine pada SBW sebagai reseptor (Suzuki et al., 2001; Helmi et al., 2018).

\section{Meningkatkan Kesehatan Jantung dan Pembuluh Darah}

Angiotensin-converting enzyme (ACE) sebagian besar terlibat dalam peningkatan tekanan darah tubuh (Belovic et al., 2013). Peptida SBW seperti tirosin, triptofan, prolin, fenilalanin, lisin, leusin, isoleusin, valin, dan arginin memiliki pengaruh kuat pada ikatan ACE dan menghambat aktivitas enzim ACE (Daskaya-Dikmen et al., 2017). Glikoprotein SBW yang dihidrolisis oleh enzim alkalase menunjukkan aktivitas penghambatan ACE tertinggi dengan nilai $\mathrm{IC}_{50}$ yaitu 0,02 $\mathrm{mg}$ protein/ml (Nurfatin et al., 2016). Optimalisasi hidrolisis enzimatik pada glikoprotein SBW menunjukkan penghambatan ACE dengan nilai $\mathrm{IC}_{50} 0,514 \mathrm{mg} / \mathrm{ml}$ berada pada suhu $60^{\circ} \mathrm{C}$; $\mathrm{pH} 8,5$; rasio enzim terhadap substrat 1,5\%; dan waktu hidrolisis 4 jam (Amiza et al., 2014). Studi-studi ini menunjukkan bahwa glikoprotein SBW memiliki potensi untuk menjadi inhibitor ACE yang kuat serta bermanfaat bagi kesehatan jantung dan pembuluh darah.

\section{Meningkatkan Imunitas}

Sarang burung walet secara tradisional digunakan sebagai makanan yang dapat meningkatkan imunitas. Mei et al. (1994) melaporkan bahwa suplementasi SRW nada mencit dan tikı meninokatkan sintesis 
DNA limfosit $T$, kadar serum imunoglobulin $M(\lg M)$, dan superoksida dismutase (SOD). Penelitian lain oleh Zhao et al. (2016) melaporkan bahwa SBW mengaktivasi sel-B dan meningkatkan konsentrasi IgM, IgA, IgE dan IgG3.

\section{Efek Neuroprotektif Neurodegeneratif)}

(Mencegah

Sarang burung walet telah terbukti menunjukkan efek neuroprotektif (Yew et al., 2014). Yew et al. (2014) menemukan bahwa ekstrak SBW menurunkan tingkat neurotoksin 6-hydroxydopamine (6OHDA) terinduksi akibat perubahan apoptosis pada sel neuroblastoma SH-SY5Y manusia dan meningkatkan viabilitas sel dalam model penyakit Parkinson yang diinduksi neurotoksin. Berdasarkan hasil tersebut itu, SBW berpotensi digunakan untuk melindungi tubuh dari gangguan neurodegeneratif.

\section{Mencegah Penyakit Diabetes}

Sarang burung walet terbukti menghambat produksi TNF-a pada penelitian mengenai efek SBW terhadap resistensi insulin yang diinduksi diet tinggi lemak pada tikus (Vimala et al., 2012). Peningkatan kadar TNF- $a$ telah dikaitkan dengan diabetes. Yida et al. (2015) melaporkan bahwa SBW secara signifikan menurunkan kadar insulin, kolesterol total dan leptin, yang diduga karena pengurangan stres oksidatif oleh SBW. Sarang burung walet juga menghasilkan regulasi transkripsional gen pensinyalan insulin hati yang meningkatkan homeostasis lipid dan glukosa serta meningkatkan sensitivitas insulin (Hou et al., 2015).

\section{Klaim Fungsi Lain}

\section{Ploriferasi Sel}

Ekstrak SBW mampu meningkatkan proliferasi sel dengan menggunakan colonic adenocarcinoma cell line (sel Caco-2) sebagai model sistem. Sel Caco-2 sebagai sel inang digunakan dalam studi proliferasi sel untuk meniru karakteristik cell line usus manusia (Aswir dan Wan Nazaimoon, 2011). Sarang burung walet juga memiliki kemampuan untuk respons mitogenik. Efek proliferasi sel induk yang berasal dari adiposa manusia dapat diinduksi oleh SBW melalui peningkatan ekspresi gen IL-6 dan vascular endothelial growth factor (VEGF) yang dimediasi oleh aktivasi Nuclear factor kappa B (NF-kB) (Roh et al., 2012). Nuclear factor kappa $B$ adalah suatu bentuk protein di dalam sitoplasma sel yang terikat dalam bentuk inaktif yang berfungsi mengatur inflamasi, respons imun, penyembuhan luka, serta kematian dan fungsi sel (Gilmore, 2006). Abidin et al. (2011) melakukan penelitian terhadap efek SBW pada keratosit kornea dari kelinci, melaporkan bahwa SBW konsentrasi rendah dapat digunakan secara sinergis memicu proliferasi sel dan pemeliharaan fungsional sel, terutama untuk penyembuhan luka kornea.

\section{Aktifitas Epidermal Growth Factor dan Anti Penuaan}

Sarang burung walet mengandung komponen epidermal growth factor (EGF)-like yang mampu merangsang penggabungan timidin dalam kultur sel dari sel 3T3 fibroblas (Kong et al., 1987). Kehadiran komponen EGF yang ditemukan dalam SBW juga telah dikaitkan dengan perannya dalam pembelahan sel, pertumbuhan dan peningkatan regenerasi jaringan. Aktifitas ini berkaitan dengan fungsi SBW dalam ploriferasi sehingga dianggap bermanfaat dalam meremajakan kulit.

\section{Memperbaiki Fungsi Saluran Pencernaan}

Manfaat lain SBW yaitu dapat membantu masalah pencernaan (Ma dan Liu, 2012a). Sifat prebiotik dari SBW akan menambah nilai manfaatnya di lingkungan usus manusia. Penelitian mengenai karbohidrat sebagai prebiotik telah dilakukan oleh Sarbini dan Rastall (2011) yang diduga dipengaruhi oleh komposisi monosakarida, glikosida, dan massa molekul karbohidrat. Glikan SBW terbukti memiliki kemampuan untuk menjadi prebiotik melalui penelitian yang menggunakan model usus manusia secara in vitro (Daud et al., 2019a).

\section{Peningkatan Kekuatan Tulang}

Sarang burung walet kaya akan proteoglikan yang mengandung kondroitin glikosaminoglikan yang tidak tersulfasi (tidak terkonjugasi dengan asam sulfat). Kondroitin glikosaminoglikan ini memiliki sifat serupa dengan matriks tulang rawan ( $\mathrm{Ma}$ dan Liu, 2012a; Chua et al., 2013). Sebanyak 0,5-1,0\% ekstrak SBW meningkatkan proliferasi kondrosit artikular manusia. Selain itu, SBW juga mengurangi aktivitas katabolik dengan mengurangi ekspresi gen katabolik seperti matrix metalloproteinases. Hal ini karena sialoglikoprotein yang ditemukan dalam SBW adalah bahan matriks tulang rawan. Oleh karena itu, SBW dapat digunakan untuk mengontrol perkembangan osteoartritis dan mempromosikan sel-sel tulang rawan untuk beregenerasi (Chua et al., 2013). Konsumsi SBW pada tikus yang diovariektomi meningkatkan kekuatan tulang femur dan konsentrasi kalsium. Sarang burung walet meningkatkan ketebalan kulit, kalsium, fosfor, dan tingkat 
Selain itu, kandungan asam sialat pada SBW diketahui berperan dalam perkembangan ovarium. Asam sialat berfungsi sebagai sumber nutrisi terpenting untuk pertumbuhan folikel ovarium (Marni et al., 2014) dan endometrium manusia yang diatur oleh hormon estradiol (Sen et al., 2001). Asam sialat SBW yang membentuk persentase gula tertinggi merupakan senyawa penting pada sebagian besar sel hewan dengan fungsi biologis penting seperti komunikasi sel dan pensinyalan (Gheri et al., 2009). Sarang burung walet dapat digunakan untuk meningkatkan fungsi dan reproduksi uterus dengan meningkatkan proliferasi struktur uterus seperti sel epitel luminal, sel epitel glandular, dan sel stroma (Albishtue et al., 2019).

\section{Antioksidan}

Sifat antioksidan SBW bermanfaat untuk penyakit kardiometabolik (Hou et al., 2015). Sarang burung walet mengandung bahan mudah dicerna dan bahan sulit dicerna. Bahan sulit dicerna memiliki aktivitas antioksidan yang rendah, sedangkan bahan mudah dicerna meningkatkan aktivitas antioksidan pada konsentrasi yang sama (Yida et al., 2014). GlikoproteinSBW yang diproduksi oleh enzim alkalase membawa aktivitas antioksidan yang kuat (Elicia et al., 2014).

Asam amino pada SBW memiliki sifat antioksidan tinggi berupa asam amino aromatik (tirosin, histidin, triptofan, dan fenilalanin) (Zou et al., 2016) dan asam amino hidrofobik (Nadia et al., 2017). Asam amino aromatik mengubah reactive oxygen species (ROS) menjadi molekul stabil dengan menyumbangkan elektron. Reactive oxygen species dihasilkan pada saat terjadinya metabolisme oksidatif dalam tubuh seperti proses oksidasi makanan menjadi energi. Reactive oxygen species memiliki kecenderungan memperoleh elektron dari substansi lain yang menjadikan radikal bebas bersifat reaktif. Asam amino histidin juga merupakan scavenger yang efektif dan merupakan ligan bagi unsur logam (Chen et al., 1998). Tripeptide yang mengandung tirosin dan triptofan pada C-termini terbukti sebagai scavenger kuat terhadap bahan radikal bebas (Saito et al., 2003).

Asam amino hidrofobik memfasilitasi interaksi pada media yang bersifat hidrofobik, sehingga meningkatkan bioavailabilitas sifat antioksidan (Himalaya et al., 2012). Ghassem et al. (2017) menemukan bahwa dua pentapeptide SBW dari A. fuciphagus menunjukkan nilai oxygen radical absorbance capacity (ORAC) tertinggi. Oxygen radical absorbance capacity adalah ukuran aktivitas atau efisiensi antioksidan makanan dan minuman tertentu yang dianggap sebagai metode pilihan untuk mengukur kekuatan antioksidan.

Efektivitas antioksidan SBW diuji pada lalat buah (Drosophila melanogaster) hidup. Lalat pada kelompok perlakuan SBW menunjukkan tingkat kematian yang lebih rendah, tingkat kelangsungan hidup terhadap stres panas lebih tinggi, dan umur lebih panjang dibandingkan dengan kelompok lalat tanpa perlakuan (Hu et al., 2016). Studi tersebut telah menunjukkan aktivitas antioksidan SBW untuk menunda proses penuaan. Sup SBW mengandung aktivitas antioksidan yang lebih tinggi dibandingkan dengan sup ayam dan ikan apabila disajikan dengan cara yang sama (Lee, 2014). Produk siap minum yang digabungkan dengan glikoprotein SBW menunjukkan aktivitas antioksidan yang secara signifikan lebih tinggi dibandingkan dengan glikoprotein SBW saja atau minuman tanpa SBW (Mohd Khan et al., 2014).

Hasil penelitian telah mengungkap beberapa manfaat sarang burung walet sebagai pangan fungsional. Penelitian yang lebih luas dapat dilakukan untuk mengeksplorasi efek fisiologis dan mekanisme bahan bioaktif fungsional SBW dalam sistem kesehatan manusia. Glikoprotein dan nutrisi lain dari SBW dapat digunakan sebagai bahan makanan aktif dalam pangan fungsional, suplemen makanan, produk farmasi dan kosmetik.

Kelebihan penggunaan SBW dalam industri makanan yaitu mudah diaplikasikan, mudah dalam ekstraksi dan mudah dimurnikan. Selain itu, bahan bioaktif fungsional SBW dapat disesuaikan dengan kebutuhan spesifik terkait dengan gaya hidup yang bermanfaat bagi kesehatan konsumen. Lebih lanjut lagi, penggunaan SBW ke dalam produk makanan dapat menjadi alternatif ketersediaan sumber baru bagi pengembangan produk pangan fungsional di masa depan.

\section{UCAPAN TERIMA KASIH}

Penulis mengucapkan terima kasih yang sebesarbesarnya kepada Badan Karantina Pertanian, Badan Penyuluhan dan Pengembangan Sumber Daya Manusia Pertanian-Kementerian Pertanian, serta Departemen Ilmu Penyakit Hewan dan Kesehatan Masyarakat Veteriner-Institut Pertanian Bogor. 


\section{DAFTAR PUSTAKA}

[BPOM] Badan Pengawas Obat dan Makanan. 2011. Peraturan Kepala Badan Pengawas Obat dan Makanan Republik Indonesia Nomor HK.03.1.23. 11.11.09909 tahun 2011 tentang Pengawasan Klaim dalam Label dan Iklan Pangan Olahan.

Abidin F, Hui CK, Luan NS, Ramli ESM, Hun LT, Abd Ghafar N. 2011. Effects of edible bird's nest (SBW) on cultured rabbit corneal keratocytes. BMC complementary and alternative medicine 11(1): 94. https://doi.org/10.1186/1472-6882-11-94

Albishtue AA, Yimer N, Zakaria MZA, Abubakar AA, Almhanawi BH. 2019. Effects of SBW on embryo implantation, plasma concentrations of reproductive hormones, and uterine expressions of genes of PCNA, steroids, growth factors and their receptors in rats. Theriogenology 126: 310-319.https://doi.org/ 10.1016/j.theriogenology.2018.12.026

Amiza MA, Sai JY, Norizah MS. 2014. Optimization of Enzymatic Hydrolysis Conditions on Angiotensin Converting Enzyme (ACE) Inhibitory Activity from Edible Bird's Nest. International Conference on Food Innovation. Bangkok, Thailand.

Aswir AR, Wan Nazaimoon WM. 2011. Effect of Edible Bird's Nest on Cell Proliferation and Tumor Necrosis Factor-Alpha (TNF- $\alpha$ ) Release in Vitro. International Food Research Journal 18: 1123-1127.

Babji AS, Nurfatin MH, Syarmila EIK, Masitah M. 2015. Secrets of Edible Bird's Nest. UTAR Agriculture Science Journal 1(1): 32-37.

Babji AS, Nurfatin MH, Syarmila EIK, Nadia NM, Farahniza Z, Norhasidah S. 2014. Research on Functional Properties and Product Development from Swiftlet Edible Bird Nest. INNOVA Food 2014 International Conference on Food Innovation. Penang, Malaysia.

Babji AS. 2014. Review: Development of Downstream Products from Edible Bird's Nest. Edible Bird's Nest Industry Conference. Putrajaya. Malaysia.

Belović MM, llić NM, Tepić AN, Šumić ZM. 2013. Selection of Conditions for AngiotensinConverting Enzyme Inhibition Assay: Influence of Sample Preparation and Buffer. Food \& Feed Research 40(1): 11-15.

Carbonaro M, Maselli P, Nucara A. 2012. Relationship between digestibility and secondary structure of raw and thermally treated legume proteins: a Fourier transform infrared (FT-IR) spectroscopic study. Amino Acids 43: 911-921. https://doi.org/10.1007/s00726-011-1151-4
Chantler P, Driessens G. 2002. Swifts: A Guide to the Swifts \& Treeswifts of the World, $2^{\text {nd }}$ ed. A\&C Black. Edinburgh.

Chen HM, Muramoto K, Yamauchi F, Fujimoto K, Nokihara K. 1998. Antioxidative Properties of Histidine-containing Peptides Designed from Peptide Fragments Found in the Digests of a Soybean Protein. Journal of Agricultural and Food Chemistry 46: 49-53. https://doi.org/10.1021/jf970649w

Chua KH, Lee TH, Nagandran K, Yahaya NHM, Lee CT, Tjih ETT, Aziz RA. 2013. Edible Bird's nest extract as a chondro-protective agent for human chondrocytes isolated from osteoarthritic knee: in vitro study. BMC complementary and alternative medicine 13(1): 19. https://doi.org/10.1186/1472-6882-13-19

Chua LS, Zukefli SN. 2016. A Comprehensive Review on Edible Bird's Nests and Swiftlet Farming. Journal of Integrative Medicine 14(6): 415-428. https://doi.org/10.1016/S2095-4964(16)60282-0

Daskaya-Dikmen C, Yucetepe A, Karbancioglu-Guler F, Daskaya H, Ozcelik B. 2017. Angiotensin-Iconverting Enzyme (Ace)-inhibitory Peptides from Plants. Nutrition 9(4): 316. https://doi.org/10.3390/nug040316

Daud NA, Sarbini SR, Babji AS, Yusop SM, Lim SJ. 2019a. Characterization of Edible Swiftlet's Nest as a Prebiotic Ingredient Using a Simulated Colon Model. Annals of Microbiology 69(12): 1-12. https://doi.org/10.1007/s13213-019-01507-1

Daud NA, Yusop SM, Babji AS, Lim SJ, Sarbini SR, Yan HT. 2019b. Edible Bird's Nest: Physicochemical Properties, Production, and Application of Bioactive Extracts and Glycopeptides. Food Reviews International 1-20. https://doi/full/10.1080/87559129.2019.1696359

Deutz NEP, Ten Have GAM, Soeters PB, Moughan PJ. 1995. Increased intestinal amino-acid retention from the addition of carbohydrates to a meal. Clinical nutrition 14:354-364. https://doi.org/10.1016/S0261-5614(95)80053-0

Dhingra D, Michael M, Rajput H, Patil RT. 2012. Dietary fibre in foods: a review. Journal of food science and technology. 49: 255-266. https://doi.org/10.1007/s13197-011-0365-5

Elicia TYM, Nurfatin MH, Farahniza Z, Norhasidah S, Syarmila EIK, Babji AS. 2014. Effect of Enzymatic Hydrolysis on the Antioxidant Activity of Edible Bird Nest. $16^{\text {th }}$ Food Innovation Asia Conference. Bangkok, Thailand. 
Etty-Syarmila IK, Nurfatin MH, Masitah M, Farahniza Z, Ayub MK, Zalifah MK, Babji AS. 2014. Natural Antioxidant and Antihypertensive Peptides from Edible Bird Nest Hydrolysates. $18^{\text {th }}$ World Congress on Clinical Nutrition (WCCN) Agriculture, Food and Nutrition for Health and Wellness, Ubon Ratchathani, Thailand.

Fujita M, Leh C. 2020. The Feeding Ecology of EdibleNest Swiftlets in a Modified Landscape in Sarawak. In Anthropogenic Tropical Forests (pp. 401415). Springer. Singapore. https://doi.org/10.1007/978-981-13-7513-2_19

Ghassem M, Arihara K, Salimeh M, Norrakiah AS, Babji AS. 2017. Identification of Two Novel Antioxidant Peptides from Edible Bird Nest (Aerodramus fuciphagus) Protein Hydrolysate. Food and Function 00:1-7. https://doi.org/10.1039/C6FO01615D

Gheri G, Vichi D, Thyrion GZ, Bonaccini L, Vannelli G, Marini M, Sgambati E. 2009. Sialic acid in human testis and changes with aging. Reproduction, Fertility and Development 21: 625-633. https://doi.org/10.1071/RD08292

Gilmore TD. 2006. Review Introduction to NF-kB: players, pathways, perspectives. Oncogene. 25: 6680-6684.

https://doi.org/10.1038/sj.onc.1209954

Goh DLM, Chua KY, Chew FT, Seow TK, Ou KL, Yi FC, Lee BW. 2001. Immunochemical characterization of edible bird's nest allergens. Journal of Allergy and Clinical Immunology 107(6): 1082-1088. https://doi.org/10.1067/mai.2001.114342

Guo C, Takahashi T, Bukawa W, Takahashi N, Yagi H, Kato K, Hidari KI, Miyamoto D, Suzuki T, Suzuki Y. 2006. Edible Bird's Nest Extract Inhibits Influenza Virus Infection. Antiviral Research 70: 140-146. https://doi.org/10.1016/j.antiviral.2006.02.005

Guzeloglu-Kayisli O, Kayisli UA, Taylor HS. 2009. The role of growth factors and cytokines during implantation: endocrine and paracrine interactions. Seminars in Reproductive Medicine 62-79. https://doi.org/10.1055 / s-0028-1108011

Haghani A, Mehrbod P, Safi N, Aminuddin NA, Bahadoran A, Omar AR, Ideris A. 2016. In vitro and in vivo mechanism of immunomodulatory and antiviral activity of edible Bird's Nest (SBW) against influenza a virus (IAV) infection. Journal of ethnopharmacology 185: 327-340. https://doi.org/10.1016/j.jep.2016.03.020

Han M, Bertram HC. 2017. Designing Healthier Comminuted Meat Products: Effect of Dietary Fibers on Water Distribution and Texture of a
Fat-Reduced Meat Model System. Meat Science 133: 159-165. https://doi.org/10.1016 /j.meatsci.2017.07.001

Helmi, Harimurti N, Dharmayanti NLPI, Mranata B, Sudarnika E, Lukman DW, Wibawan IWT. 2018. Antiviral activity of edible bird's nest extract on highly pathogenic avian influenza $\mathrm{H}_{5} \mathrm{~N}_{1}$ viral infection in vitro. Human and Veterinary Medicine 10(2): 62-68.

Himaya SW, Ryu B, Ngo DH, Kim SK. 2012. Peptide Isolated from Japanese Flounder Skin Gelatin Protects against Cellular Oxidative Damage. Journal of Agricultural and Food Chemistry 60: 9112-9119. https://doi.org/10.1021/jf302161m

Hou Z, Imam MU, Ismail M, Ooi DJ, Ideris A, Mahmud R. 2015. Nutrigenomic effects of edible bird's nest on insulin signaling in ovariectomized rats. Drug design, development and therapy 9: 4115. https://doi.org/10.2147/DDDT.S80743

Hu Q, Li G, Yao H, He S, Li H, Liu S, Wu Y, Lai X. 2016. Edible Bird's Nest Enhances Antioxidant Capacity and Increases Lifespan in Drosophila melanogaster. Cellular and Molecular Biology 62(4): 116-122.

Hun LT, Waseem AW, Eddie TTT, Ardawati NA, Ling YL, Ramlan AA. 2015. Investigations into the Physicochemical, Biochemical and Antibacterial Properties of Edible Bird's Nest. Journal of Chemical and Pharmaceutical Research 7(7): 228-247.

Jong CH, Tay KM, Lim CP. 2013. Application of the fuzzy failure mode and effect methodology to edible bird nest processing. Computers and electronics in agriculture 96: 9008. https://doi.org/10.1016/j.compag.2013.04.015

Kang N, Hails CJ, Sigurdsson JB. 1991. Nest construction and egg-laying in edible-nest swiftlets Aerodramus spp. and the implications for harvesting. IBIS 133(2): 170-177. https://doi.org/10.1111/j.1474-919X.1991.tb04828.x

Kathan RH, Weeks DI. 1969. Structure studies of Collocalia mucoid I. Carbohydrate and amino acid composition. Archives of Biochemistry and Biophysics 134(2): 572-576. https://doi.org/10.1016/0003-9861(69)90319-1

Kim SK, Jeon YJ, Byun HG, Park PJ. 1999. Calcium Absorption Acceleration Effect on Phosphorylated and Nonphosphorylated Peptides from Hoki (Johnius belengeri) Frame. Journal-Korean Fisheries Society 32: 713-717.

Kong HK, Wong KH, Lo SCL. 2016. Identification of peptides released from hot water insoluble 
fraction of edible bird's nest under simulated gastrointestinal conditions. Food Research International 85: 19-25. https://doi.org/10.1016 /j.foodres.2016.04.002

Kong YC, Keung WM, Yip TT, Ko KM, Tsao SW, Ng MH. 1987. Evidence that Epidermal Growth Factor Is Present in Swiftlet's (Collocalia) Nest. Comparative Biochemistry and Physiology B. 87(2): 221-226. https://doi.org/10.1016/03050491(87)90133-7

Koon LC, Cranbrook E. 2002. Swiftlets of BorneoBuilders of Edible Nests. Sabah, Malaysia: Natural History Publication (Borneo) SDN. BHD.

Koropatkin NM, Cameron EA, Martens EC. 2012. How glikan metabolism shapes the human gut microbiota. Nat Rev Microbiol. 10:323. https://doi.org/10.1038/nrmicro2746

Lee KS. 2014. Effects of Particle Size and Double Boiling Time on the Antioxidant Activities of Bird Nest Soup (Collocalia fuciphaga). Undergraduate Thesis, Food Science Program, Universiti Kebangsaan Malaysia. https://doi.org/10.1080/ 87559129.2019.1696359

Lee TH, Wani WA, Koay YS, Kavita S, Tan ETT, Shreaz S. 2017. Recent advances in the identification and authentication methods of edible bird's nest. Food Research International 100: 14-27. https://doi.org/10.1016/j.foodres.2017.07.036

Lin JR, Zhou H, Lai XP, Hou Y, Xian XM, Chen JN, Wang PX, Zhou L, Dong Y. 2009. Genetic identification of edible birds' nest based on mitochondrial DNA sequences. Food Research International 42(8): 1053-1061. https://doi.org/10.1016/j.foodres.2009.04.014

Ma F, Liu D. 2012a. Sketch of the edible bird's nest and its important bioactivities. Food Research International 48(2): 559-567. https://doi.org/10.1016/j.foodres.2012.06.001

Ma FC, Liu DC. 2012b. Extraction and Determination of Hormones in the Edible Bird's Nest. Asian Journal of Chemistry 24(1): 117-120.

Marcone MF. 2005. Characterization of the Edible Bird's Nest the "Caviar of the East". Food Research International 38(10): 1125-1134. https://doi.org/10.1016/j.foodres.2005.02.008

Mardiastuti A. 1997. Pemanfaatan Sarang Burung Walet secara Lestari. Makalah pada Seminar Pendayagunaan Potensi Burung Untuk Menunjang Pembangunan Nasional. Taman Burung Taman Mini Indonesia Indah, Jakarta, 29 April 1997.
Marni S, Marzura MR, Norzela AM, Khairunnisak M, Bing $\mathrm{CH}$, Eddy AA. 2014. Preliminary study on free sialic acid content of edible bird nest from johor and kelantan. Malaysian Journal of Veterinary Research 5(1): 9-14.

Matsukawa N, Matsumoto M, Bukawa W, Chiji H, Nakayama K, Hara H, Tsukahara T. 2011. Improvement of bone strength and dermal thickness due to dietary edible bird's nest extract in ovariectomized rats. Bioscience, biotechnology, and biochemistry 11020223761102022376. https://doi.org/10.1271/bbb.100705

Mei Z, Daosheng W, Jian W. 1994. The effect of the Zhenzhu-Yanwo extracts on animal function [ $\mathrm{J}$ ]. Pharmaceutical Biotechnology 2.

Mohd Khan A, Syarmila EIK, Nurfatin MH, Farahniza Z, Engku Hanisah EU, Norhasidah S, Masitah EH, Masturah AK, Nurul'Ain M, Maaruf AG, Abdul Salam B. 2014. Antioxidative Properties of Readyto-drink Products Incorporated with Enzymatically Hydrolysed Edible Bird Nest. Edible Bird Nest Industry Conference. Putrajaya, Malaysia.

Nadia NM, Babji AS, Ayub MK, Nur'Aliah D. 2017. Effect of Enzymatic Hydrolysis on Antioxidant Capacity of Cave Edible Bird's Nests Hydrolysate. International Journal of ChemTech Research 10 (2): 1100-1107.

Nugroho HK, Budiman A. 2009. Panduan Lengkap Walet. Jakarta (ID): Penebar Swadaya.

Nurfatin MH, Syarmila EIK, Nur'Aliah D, Zalifah MK, Babji AS, Ayob MK. 2016. Effect of Enzymatic Hydrolysis on Angiotensin Converting Enzyme (ACE) Inhibitory Activity in Swiftlet Saliva. International Food Research Journal 23(1): 141-146.

Pintado T, Ruiz-Capillas C, Jiménez-Colmenero $F$, Carmona P, Herrero AM. 2015. Oil-in-water Emulsion Gels Stabilized with Chia (Salvia hispanica L.) and Cold Gelling Agents: Technological and Infrared Spectroscopic Characterization. Food Chemistry185:470-478. https://doi.org/10.1016/j.foodchem.2015.04.024

Quek MC, Chin NL, Yusof YA, Law CL, Tan SW. 2018. Characterization of edible bird's nest of different production, species and geographical origins using nutritional composition, physicochemical properties and antioxidant activities. Food Research International 109: 35-43. https://doi.org/10.1016/j.foodres.2018.03.078. 
Ravisangkar R, Nurfatin MH, Etty Syamila IK, Masitah M, Norhasidah S, Babji AS. 2014. Effects of Adding Edible Bird Microparticulates on the Oxidation of Chicken Burger. Malaysian Journal of Animal Science 17(2): 55-72.

Roh KB, Lee J, Kim YS, Park J, Kim JH, Lee J, Park D. 2012. Mechanisms of edible bird's nest extractinduced proliferation of human adipose-derived stem cells. Evidence-Based Complementary and Alternative Medicine: eCAM, 2012.

Saengkrajang W, Matan N, Matan N. 2013. Nutritional Composition of the Farmed Edible Bird's Nest (Collocalia fuciphaga) in Thailand. Journal of food composition and analysis 31: 4145. https://doi.org/10.1016/j.jfca.2013.05.001

Saito K, Jin DH, Ogawa T, Muramoto K, Hatakeyama E, Yasuhara T, Nokihara K. 2003. Antioxidative Properties of Tripeptide Libraries Prepared by the Combinatorial Chemistry. Journal of Agricultural and Food Chemistry 51: 3668-3674. https://doi.org/10.1021/jf021191n

Sarbini SR, Rastall RA. 2011. Prebiotics: Metabolism, Structure, and Function. Functional Food Reviews 3(3): 93-106.

Sawicki CM, Livingston KA, Obin M, Roberts SB, Chung M, McKeown NM. 2017. Dietary fiber and the human gut microbiota: Application of evidence mapping methodology. Nutrients 9: 125. https://doi.org/10.3390/nu9020125

Sen S, Chowdhury G, Chowdhury M. 2001. Sialic acid binding protein of human endometrium: Its regulation by steroids. Molecular and Cellular Biochemistry 221: 17-23. https://doi.org/10.1023/A:1010901303113

Shim EK, Chandra GF, Pedireddy S, Lee SY. 2016. Characterization of swiftlet edible bird nest, a mucin glycoprotein, and its adulterants by Raman microspectroscopy. Journal of food science and technology 53(9): 3602-3608. https://doi.org/10.1007/s13197-016-2344-3

Soehartono T, Mardiastuti A. 2003. Pelaksanaan Konvensi CITES di Indonesia. Jakarta (ID): JICA

Sovrani V, de Jesus LI, Simas-Tosin FF, Smiderle FR, lacomini M. 2017. Structural Characterization and Rheological Properties of a Gel-like $\beta$-d-glucan from Pholiota nameko. Carbohydrate Polymers 169:1-8.

https://doi.org/10.1016/j.carbpol.2017.03.093

Suzuki T, Portner A, Scroggs RA, Uchikawa M, Koyama N, Matsuo K, Suzuki Y, Takimoto T. 2001. Receptor Specificities of Human Respiroviruses. Journal of Virology 75: 4604-4613. https://doi.org/10.1128/JVI.75.10.4604-4613.2001
Tailford LE, Crost EH, Kavanaugh D, Juge N. 2015. Mucin glikan foraging in the human gut microbiome. Front Genet. 6:81. https://doi.org/10.3389/fgene.2015.00081

Utomo B, Rosyidi D, Radiati LE, Puspaningsih NNT, Proborini WD. 2014. Protein Characterization of Extracted Water from Three Kinds of Edible Bird Nest Using SDS-PAGE CBB Staining and SDSPAGE Glycoprotein Staining and LC-MS/MS Analyses. IOSR Journal of Agriculture and Veterinary Science 7(9): 33-38.

Vimala B, Hussain H, Wan Nazaimoon W. 2012. Effects of edible bird's nest on tumour necrosis factor-alpha secretion, nitric oxide production and cell viability of lipopolysaccharide-stimulated RAW 264.7 macrophages. Food and agricultural immunology 23(4): 303-314. https://doi.org/10.1080/09540105.2011.625494

Viruhpintu S, Thirakhupt K, Pradatsundarasar A, Poonswad P. 2002. Nest-site characteristics of the edible-nest swiftlet Aerodramus fuciphagus (thunberg, 1812) at Si-ha islands, Phattalung province, Thailand. Natural History. Thailand. 2: 31-35.

Wong CF, Chan GKL, Zhang ML, Yao P, Lin HQ, Dong TTX, Li G, Lai XP, Tsim KWK. 2017. Characterization of Edible Bird's Nest by Peptide Fingerprinting with Principal Component Analysis. Food Quality and Safety 1(1): 83-92. https://doi.org/10.1093/fqsafe/fyxoo2

Wong RSY. 2013. Edible Bird's Nest: Food or Medicine. Chinese journal of integrative medicine 19(9), 643-649. https://doi.org/10.1007/s11655013-1563-y

Xian XM, Hou Y, Lin JR, Huang S, Lai XP, Chen JN. 2010. Study on Degradation of Protein of the Edible Birds' Nest (Aerodramus) in Vitro. Journal of Chinese medicinal materials 33(11): 1760-1763.

Xu H, Zheng L, Xie Y, Zeng H, Fan Q, Zheng B, Zhang $Y$. 2019. Identification and determination of glycoprotein of edible brid's nest by nanocomposites based lateral flow immunoassay. Food Control 102: 214-220. https://doi.org/10.1016/j.foodcont.2019.03.018

Yagi H, Yasukawa N, Yu SY, Guo CT, Takahashi N, Takahashi T, Bukawa W, Suzuki T, Khoo KH, Suzuki Y, Kato K. 2008. The expression of sialylated high-antennary $\mathrm{N}$-glikans in edible bird's nest. Carbohydr Res. 343:1373-1377. https://doi.org/10.1016/j.carres.2008.03.031

Yew MY, Koh RY, Chye SM, Othman I, Ng KY. 2014. Edible bird's nest ameliorates oxidative stress-induced apoptosis in SH-SY5Y human 
neuroblastoma cells. BMC complementary and alternative medicine 14(1): 1-12. https://doi.org/10.1186/1472-6882-14-391

Yida Z, Imam MU, Ismail M. 2014. In vitro bioaccessibility and antioxidant properties of edible bird's nest following simulated human gastrointestinal digestion. BMC complementary and alternative medicine 14(1): 468. https://doi.org/10.1186/1472-6882-14-468

You Y, Cao Y, Guo S, Xu J, Li Z, Wang J, Xue C. 2015. Purification and identification of a 2-3 linked sialoglycoprotein and a 2-6 linked sialoglycoprotein in edible bird's nest. European Food Research and Technology 240: 389-397. https://doi.org/10.1007/s00217-014-2338-1

Zainab H, Hulwani NI, Sarojini J, Kamarudin H, Othman H, Lee B. 2013. Nutritional Properties of Edible Bird's Nest. Asian Journal of Scientific Research 3(6): 600-607.

Zhang S, Lai X, Liu X, Li Y, Li B, Huang X, Zhang Q, Chen W, Lin L, Yang G. 2012. Competitive enzymelinked immunoassay for sialoglycoprotein of edible bird's nest in food and cosmetics. Journal of Agricultural and Food Chemistry 60(14): 3580-3585. https://doi.org/10.1021/jf300865a

Zhao R, Li G, Kong XJ, Huang XY, Li W, Zeng YY, Lai $X P$. 2016. The improvement effects of edible bird's nest on proliferation and activation of $B$ lymphocyte and its antagonistic effects on immunosuppression induced by cyclophosphamide. Drug Design, Development and Therapy 10: 371-381. https://dx.doi.org/10.2147\%2FDDDT.S88193

Zhiping $\mathrm{H}$, Imam $\mathrm{MU}$, Ismail $\mathrm{M}$, Ismail N, Yida Z, Ideris A, Sarega N, Mahmud R. 2015. Effects of edible bird's nest on hippocampal and cortical neurodegeneration in ovariectomized rats. Food \& function 6(5): 1701-1711. https://doi.org/10.1039/C5FOo0226E

Zou TB, He TP, Li HB, Tang HW, Xia EQ. 2016. The Structure-activity Relationship of the Antioxidant Peptides from Natural Proteins. Molecules 21(1): 72. https://doi.org/10.3390/molecules21010072 